JPPIPA, Vol.3 No.1 2018
Jurnal Penelitian Pendidikan IPA
htt//journal.unesa.ac.id/index.php/jppipa

\title{
PEMANFAATAN INDIKATOR ALAM DALAM MEWUJUDKAN PEMBELAJARAN KIMIA BERWAWASAN GREEN CHEMISTRY
}

Oleh:

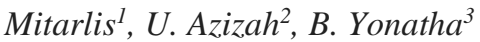

1,2,3 Jurusan Kimia, Fakultas MIPA, Universitas Negeri Surabaya, Surabaya 60231, Indonesia.

\begin{abstract}
Abstrak
Telah dilakukan penelitian pengembangan bahan ajar mata kuliah Kimia Dasar dengan wawasan green chemistry. Kimia sebagai ilmu yang berdasarkan eksperimen, tidak lepas dari aktivitas laboratorium yang membutuhkan bahan kimia, yang biasanya didapatkan dari industri bahan kimia. Sebenarnya kimia sangat dekat dengan kehidupan keseharian siswa. Oleh karena itu pembelajaran kimia dirancang dengan memanfaatkan produk alami disekitar siswa. Salah satunya dengan memanfaatkan beberapa jenis tanaman atau bunga berwarna yang ada disekitar kehidupan siswa sebagai indikator asam dan basa alami. Metode penelitian menggunakan rancangan penelitian pengembangan (R\&D). Hasil penelitian menunjukkan bahwa pemanfaatan produk alami terbarukan sebagai pendukung pembelajaran dapat memenuhi salah satu prinsip green chemistry yaitu "penggunaan bahan baku terbarukan". Dalam penelitian ini beberapa bunga berwarna diidentifikasi dan berpotensi dimanfaatkan sebagai indikator asam basa alami dalam pembelajaran kimia antara lain bunga pacar air dan Ruellia. Dengan menggunakan bahan alami dapat menjaga keberlanjutan proses pembelajaran kimia tanpa tergantung bahan kimia buatan industri.
\end{abstract}

Kata Kunci : green chemistry, pembelajaran kimia, indikator alami.

\begin{abstract}
Research has been done to develop basic chemistry course subject with green chemical insight. Chemistry as a basis based on experimentation, is not separated from activities that require chemicals, which are usually obtained from the chemical industry. Actually chemistry is very close to the daily life of students. Therefore learning chemistry is designed by utilizing the student's natural products. One of them by using some kind of plants or flowers that exist there as a natural acid and base indicator. Research method using research development $(R \&$ $D)$. The results show that the use of the product can support one of the principles of green chemistry that is "the use of renewable raw materials". In this study are some things that can be done as an indicator of acid in the chemical environment and others. By using materials that can affect chemical processes independently of industrial-made chemicals.
\end{abstract}

Keywords: green chemistry, chemistry learning, natural indicators.

(C) 2018 Universitas Negeri Surabaya

Alamat Korespondensi:

Jurusan IPA, Fakultas MIPA, Universitas

p-ISSN: 2527-7537

Negeri Surabaya, Surabaya 60231, Indonesia

e-ISSN: 2549-2209

Email: mitarlis@unesa.ac.id 


\section{PENDAHULUAN}

Eksperimen, tidak lepas dari aktivitas laboratorium yang membutuhkan bahan kimia, yang biasanya didapatkan dari industri bahan kimia. Sebenarnya kimia sangat dekat dengan kehidupan keseharian siswa. Hal ini juga seperti yang dinyatakan Sugiarto (2007: 2) bahwa dunia kita adalah dunia kimia, setiap hari kita berenangrenang dalam lautan kimia. Hal ini berarti kimia tidak pernah terlepas dari kehidupan manusia dan sebaliknya manusia tidak pernah terlepas dari kimia, baik dalam kehidupan, sehari-hari, industri, bahkan dalam pembelajaran khususnya pembelajaran kimia. Oleh karena itu pembelajaran kimia dapat dirancang dengan memanfaatkan produk alami disekitar siswa. Salah satunya dengan memanfaatkan beberapa jenis tanaman atau bunga berwarna yang ada disekitar kehidupan siswa sebagai indikator asam dan basa alami.

Berdasarkan kurikulum pembelajaran yang berlaku di Indonesia, materi kimia mulai diberikan pada tingkat SMP dalam mata pelajaran IPA. Pada tingkat SMA/SMK mata pelajaran kimia diberikan sebagai mata pelajaran tersendiri (Kemdikbud, 2013). Pada tingkat perguruan tinggi bidang studi kimia juga diberikan untuk program studi teknik MIPA (Kimia) atau program studi MIPA sebagai mata kuliah Kimia Dasar.

Mata kuliah Kimia Dasar sebagai cabang IPA beserta kegiatan praktikumnya, sangat berpeluang untuk mengimplementasikan pendidikan lingkungan dalam rangka mewujudkan Green Education. Dalam pelaksanaan proses pembelajaran di kelas maupun di laboratorium selama ini sebenarnya telah tersisip nilai-nilai karakter khususnya yang berwawasan green chemistry yang kadang kala kita tidak menyadarinya. Green Chemistry adalah suatu falsafah atau konsep yang mendorong desain dari sebuah produk ataupun proses yang mengurangi ataupun mengeliminir penggunaan dan penghasilan zat-zat (substansi) berbahaya. Seperti yang dikemukakan oleh Manahan (2006).

"Green chemistry is the practice of chemistry in a manner that maximizes its benefits while eliminating or at least greatly reducing its adverse impacts. Green chemistry is the sustainable practice of chemical science and manufacturing within a framework of industrial ecology in a manner that is sustainable, safe, and non-polluting, consuming minimum amounts of energy and material resources while producing virtually no wastes".

Green chemistry mempunyai 12 azas atau prinsip yang dapat diadaptasi untuk diaplikasikan dalam sikap dan tindakan manusia dalam upaya penyelamatan lingkungan. Tindakan penyelamatan lingkungan dapat dilakukan sejak dini dengan mengimplementasikan di bidang pendidikan pada semua jenjang yang dapat terwujud melalui green education. Berdasarkan hasil penelitian Mitarlis (2015) hasil analisis karakter sains khususnya sains kimia berwawasan green chemistry dalam rangka mewujudkan green education melalui mata kuliah Kimia Dasar didapatkan beberapa nilai karakter yang dapat diimplementasikan dalam pembelajaran, didapatkan simpulan antara lain: Nilai karakter umum yang dapat dimunculkan dalam perkuliahan Kimia Dasar antara lain: jujur, disiplin, cermat, teliti, hati-hati, kerja keras, tanggung jawab, berpikir analitis, kritis, kreatif, dan peduli lingkungan. Identifikasi prinsip green chemistry sebagai dasar analisis nilai karakter sains berwawasan green chemistry dalam rangka mewujudkan green education didapatkan 7 prinsip green chemistry yang mendasari analisis karakter sains yaitu: pencegahan limbah, penggunaan bahan terbarukan, prinsip ekonomi atom, efisiensi energi, merancang bahan yang dapat terdegradasi, analisis waktu nyata untuk mencegah polusi, dan penciptaan kondisi aman dan mencegah terjadinya kecelakaan. Nilai karakter sains berwawasan green chemistry dari hasil pemetaan antara lain: jujur, teliti rasa ingin tahu, peduli lingkungan, hemat dan kreatif (pemanfaatan bahan alam untuk kepentingan manusaia dan pembelajaran kimia), dan lain-lain. Hasil temuan tersebut besar manfaatnya jika dapat diimplementasikan dalam pembelajaran. Salah satu prinsip green chemistry yang dapat diimplementasikan dalam pembelajaran kimia yaitu "penggunaan bahan baku yang dapat terbarukan". Dalam artikel ini disajikan hasil penelitian untuk menjawab beberapa permasalahan yaitu bagaimana pemanfaatan bahan alam sebagai indikator asam basa, bagaimana pemanfaatan indikator alam asam basa dalam pembelajaran kimia berwawasan green chemistry?

\section{METODE}

Metode penelitian menggunakan rancangan penelitian pengembangan $(R \& D)$ diadaptasi dari Sjaifullah (2011). Tahapan pengembangan terdiri dari 6 tahap yakni: studi pendahuluan, kajian pustaka, pengembangan perangkat, telaah ahli, uji empiris, dan produk akhir. Pada prinsipnya metode ini terdiri dari tiga tahap, yaitu: tahap studi pendahuluan (preliminary study) yang didukung oleh studi referensi (reference study), tahap studi pengembangan (material development), dan tahap evaluasi oleh ahli (expert evaluation).

Teknik pengumpulan data sampai pada tahap ini dilakukan dengan metode pemetaan untuk melakukan need assessment, studi literatur terkait materi pembelajaran kimia, kajian tentang green 
chemistry, dan pengembangan media pembelajaran berwawasan green chemistry dengan memanfaatkan bahan baku terbarukan. Uji coba dilakukan untuk uji kelayakan perangkat yang dikembangkan dengan mendokumentasikan berbagai perolehan selama melakukan pengembangan perangkat mulai dari tahap awal sampai akhir. Teknik analisis data dilakukan secara deskriptif kuantitatif dan kualitatif berdasarkan kesesuaian dengan data yang didapatkan.

\section{HASIL DAN PEMBAHASAN}

\section{Analisis kurikulum mata kuliah Kimia Dasar}

Analisis kurikulum dilakukan terhadap dokumen Rencana Pembelajaran Semester (RPS) mata kuliah Kimia Dasar. Dalam konteks penelitian ini kompetensi yang dicapai oleh mahasiswa dikaitkan dengan wawasan green chemistry. Dengan demikian perlu dikembangkan perangkat pembelajaran Kimia Dasar berwawasan Green Chemistry. Perangkat pembelajaran diharapkan dapat memberikan pengalaman belajar kepada mahasiswa dengan memunculkan prinsip green chemistry pada bahan kajiannya. Hasil analisis Kimia Dasar berwawasan Green chemistry topik indikator asam basa disajikan pada Tabel 1 .

Tabel 1. Data hasil analisis rps kimia dasar i berwawasan green chemistry pada topik indikator asam basa.

\begin{tabular}{|c|c|c|c|c|}
\hline No. & Bahan Kajian** & $\begin{array}{l}\text { Prinsip Green Chmeistry } \\
\text { yang dapat dimunculkan }\end{array}$ & Pengalaman Belajar & $\begin{array}{l}\text { Strategi/Model/ } \\
\text { Pembelajaran }\end{array}$ \\
\hline 1 & $\begin{array}{l}\text { Larutan: Larutan } \\
\text { elektrolit dan non } \\
\text { elektrolit, sifat } \\
\text { koligatif, asam- } \\
\text { basa, pH larutan, } \\
\text { hidrolisis, ion } \\
\text { senama, larutan } \\
\text { buffer, dan titrasi. }\end{array}$ & $\begin{array}{l}\text { Prinsip no1. } \\
\text { Mencegah / mengurangi } \\
\text { terbentuknya limbah } \\
\text { Prinsip No. } 5 \\
\text { menggunakan pelarut } \\
\text { atau bahan kimia yang } \\
\text { aman } \\
\text { Prinsip No. } 6 \\
\text { Hemat energi, hemat } \\
\text { bahan kimia saat } \\
\text { praktikum. } \\
\text { Prinsip No.7 } \\
\text { Menggunakan bahan } \\
\text { yang dapat diperbarui } \\
\text { Prinsip no. 12. } \\
\text { Mencegah kecelakaan }\end{array}$ & $\begin{array}{l}\text { 1. Merangkum, } \\
\text { mencari ide pokok } \\
\text { bahan ajar, tanya- } \\
\text { jawab, dan latihan } \\
\text { soal } \\
\text { 2. Melakukan praktikum } \\
\text { berwawasan green } \\
\text { chemistry tentang: } \\
\text { - Larutan elektrolit } \\
\text { dan non elektrolit } \\
\text { - Indikator dan } \\
\text { Praktikum titrasi } \\
\text { asam-basa } \\
\text { Uji pewarna pada } \\
\text { makanan }\end{array}$ & $\begin{array}{l}\text { 4. Praktikum tentang } \\
\text { indikator asam basa } \\
\text { alami } \\
\text { (Prinsip GC No. 5, dan } \\
\text { No. 7) }\end{array}$ \\
\hline
\end{tabular}

Berdasarkan Tabel 1 menunjukkan keterkaitan antara bahan kajian mata kuliah Kimia Dasar dengan topik indikator asam basa, prinsip green chemistry, dan pengalaman belajar mahasiswa, serta model/strategi/metode pembelajarannya. Selanjutnya dilakukan analisis pengalaman belajar Kimia Dasar pada pembelajaran di kelas atau pembelajaran di laboratorium dengan pemunculan atau pengintegrasian prinsip green chemistry beserta rasionalnya.

\section{Analisis Pengalaman Belajar Kimia Dasar berwawasan Green Chemistry}

Analisis pengalaman belajar Kimia Dasar dikaitkan dengan pemunculan prinsip green chemistry bertujuan untuk memberikan penjelasan rasional dan penentuan model/strategi/metode yang dapat digunakan dalam pembelajaran. Berdasarkan struktur kurikulum yang berlaku di Jurusan Kimia FMIPA Unesa, mata kuliah Kimia Dasar I diberikan kepada mahasiswa semester I.

Penyelenggaraan pembelajaran Kimia Dasar yang dilaksanakan di Jurusan Kimia FMIPA Unesa secara teknis dilakukan pembelajaran di kelas dan dilanjutkan dengan pelaksanaan praktikum di laboratorium. Analisis dilakukan dengan mengikuti urutan sajian bahan kajian. Hasil analisis untuk topik indikator asam basa dapat dilihat pada Tabel 2. 
Tabel 2. Data Analisis Pengalaman Belajar Kimia Dasar Terkait Prinsip Green Chemistry

\begin{tabular}{|c|c|c|c|c|}
\hline No. & Pengalaman Belajar & $\begin{array}{c}\text { Prinsip Green Chmeistry } \\
\text { (GC) yang dapat } \\
\text { dimunculkan }\end{array}$ & $\begin{array}{c}\text { Strategi/Model/ } \\
\text { Metode Pembelajaran }\end{array}$ & Rasional \\
\hline 1 & $\begin{array}{l}\text { 1. Merangkum, } \\
\text { mencari ide pokok } \\
\text { bahan ajar, tanya- } \\
\text { jawab, dan latihan } \\
\text { soal } \\
\text { 2. Melakukan } \\
\text { praktikum } \\
\text { berwawasan green } \\
\text { chemistry tentang: } \\
\text { - Larutan elektrolit } \\
\text { dan non elektrolit } \\
\text { - Indikator dan } \\
\text { Praktikum titrasi } \\
\text { asam-basa } \\
\text { Uji pewarna pada } \\
\text { makanan }\end{array}$ & $\begin{array}{l}\text { Prinsip no1. } \\
\text { Mencegah / mengurangi } \\
\text { terbentuknya limbah } \\
\text { Prinsip No. } 5 \\
\text { menggunakan pelarut } \\
\text { atau bahan kimia yang } \\
\text { aman } \\
\text { Prinsip No. } 6 \\
\text { Hemat energi, hemat } \\
\text { bahan kimia saat } \\
\text { praktikum. } \\
\text { Prinsip No.7 } \\
\text { Menggunakan bahan } \\
\text { yang dapat diperbarui } \\
\text { Prinsip no. 12. } \\
\text { Mencegah kecelakaan }\end{array}$ & $\begin{array}{l}\text { 1. Model } \\
\text { pembelajaran } \\
\text { Berbasis } \\
\text { Masalah/Problem } \\
\text { Based Learning } \\
\text { (PBL) } \\
\text { 2. Tanya jawab } \\
\text { 3. Latihan soal } \\
\text { 4. Praktikum }\end{array}$ & $\begin{array}{l}\text { - Model pembelajaran } \\
\text { berdasarkan Masalah } \\
\text { (PBL) diterapkan } \\
\text { untuk memebri } \\
\text { pengalaman belajar } \\
\text { pemecahan masalah. } \\
\text { - Pembelajaran } \\
\text { didukung oleh LKM } \\
\text { yang dikembangkan } \\
\text { - Tugas praktikum } \\
\text { yang diberikan } \\
\text { adalah tentang } \\
\text { indikator asam basa } \\
\text { alami dan titrasi. Uji } \\
\text { pewarna pada } \\
\text { makanan. } \\
\text { - Prinsip green } \\
\text { chemistry No. 1, 5, 6, } \\
\text { dan No. } 7 \text { dapat } \\
\text { dmunculkan pada } \\
\text { penyelesaian } \\
\text { praktikum }\end{array}$ \\
\hline
\end{tabular}

Berdasarkan Tabel 2 menunjukkan keterkaitan antara pengalaman belajar Kimia Dasar dengan prinsip green chemistry yang dapat dimunculkan/diintegrasikan.

Model/strategi/metode pembelajaran yang sesuai juga telah teridentifikasi beserta rasionalnya. Hasil ini akan mendasari pengembangan perangkat pembelajaran seperti Rencana Pelaksanaan Pembelajaran (RPP) atau Lembar Kegiatan Mahasiswa (LKM).

Pemunculan prinsip green chemistry sebagai wawasan yang akan diberikan kepada mahasiswa pada perkuliahan Kimia Dasar juga diidentifikasi baik untuk pembelajaran di kelas maupun di laboratorium. Implementasi dan integrasi prinsip green chemistry pada pembelajaran di di laboratorium perlu dilakukan uji coba terlebih dahulu. Hal ini sangat penting agar penerapan prinsip green chemistry dapat memberikan manfaat sesuai dengan tujuannya, namun tidak mengurangi makna dan esensi dari kegiatan praktikum yang dilakukan.

\section{Analisis Keterkaitan Antara Prinsip Green Chemistry Dan Implementasinya Pada Kegiatan Praktikum}

Hasil analisis keterkaitan antara makna prinsip green chemistry dan upaya implementasinya pada kegiatan praktikum dalam proses pengembangan perangkat pembelajaran (LKM) berwawasan green chemistry dapat dilihat pada Tabel 3. 
Tabel 3. Implementasi Prinsip Green Chemistry Pada Praktikum Kimia Dasar I

\begin{tabular}{|c|c|c|c|}
\hline No. & Judul praktikum & $\begin{array}{l}\text { Prinsip Green Chmeistry } \\
\text { yang dapat dimunculkan }\end{array}$ & $\begin{array}{c}\text { Bentuk implementasi } \\
\text { dan rasional }\end{array}$ \\
\hline 1 & $\begin{array}{l}\text { 1. Indikator asam basa } \\
\text { (alami) } \\
\text { 2. Titrasi asam basa } \\
\text { 3. Larutan penyangga } \\
\text { (TOPIK 5A) }\end{array}$ & $\begin{array}{l}\text { Prinsip no1. } \\
\text { Mencegah / mengurangi } \\
\text { terbentuknya limbah } \\
\text { Prinsip No. } \\
\text { menggunakan pelarut atau } \\
\text { bahan kimia yang aman } \\
\text { Prinsip No. } 6 \\
\text { Hemat energi, hemat bahan } \\
\text { kimia saat praktikum. } \\
\text { Prinsip No.7 } \\
\text { Menggunakan bahan yang } \\
\text { dapat diperbarui } \\
\text { Prinsip no. 12. } \\
\text { Mencegah kecelakaan }\end{array}$ & 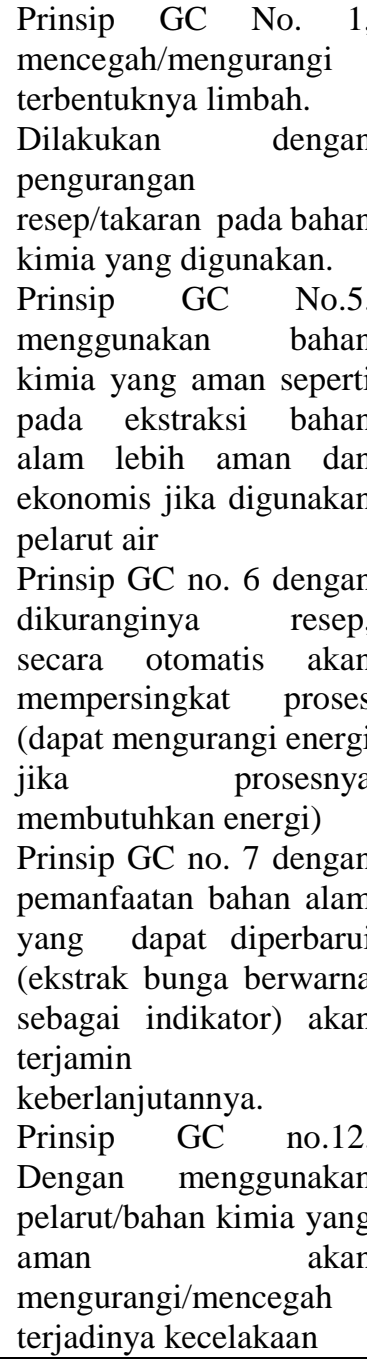 \\
\hline
\end{tabular}

Bentuk implementasi yang berhasil dianalisis dan dipetakan pada tabel 3 perlu dilakukan ujicoba terlebih dahulu untuk memastikan keberhasilan upaya penerapan prinsi-prinsip green chemistry yang telah dirancang. Uji coba kecil di lakukan di laboratorium.

\section{Uji Coba Terbatas (Laboratorium) perangkat pembelajaran LKM Praktikum Indikator asam basa alami}

Sebagai pendukung perkuliahan Kimia Dasar berwawasan green chemistry perlu dikembangkan juga LKM praktikum Kimia Dasar berwawasan green chemistry. Beberapa prinsip green chemsitry berupaya diimplementasikan pada pelaksanaan praktikum Kimia Dasar. Seperti hasil pemetaan materi praktikum atau judul praktikum yang disajikan pada Tabel 3, maka dilakukan ujicoba pada masing-masing topik. Tujuan ujicoba adalah untuk mengetahui keterterapan prinsip green chemistry tertentu pada topik tertentu dengan tidak mengurangi esensi dan makna tujuan praktikum.

\section{Hasil uji coba Laboratorium}

Praktikum dengan judul indikator asam basa alami dilakukan dengan tujuan untuk menentukan perubahan warna beberapa ekstrak tanaman (bunga berwarna) yang ada di alam yang berpotensi sebagai indikator asam basa. Secara nyata judul ini dapat memenuhi prinsip green chemsitry nomer 7 yaitu penggunaan bahan yang dapat diperbarui.

Uji coba diawali dengan persiapan alat dan bahan yang digunakan untuk praktikum indikator asam basa alami. 

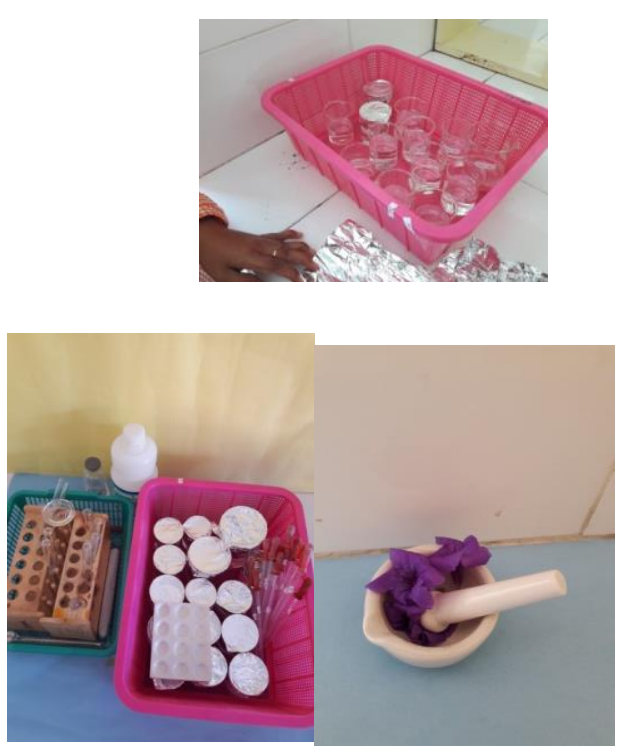

Gambar 1. Persiapan alat dan bahan percobaan indikator alam (pembuatan larutan dengan $\mathrm{pH} 1$ -

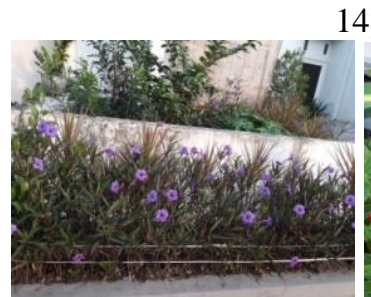

(a)
14)

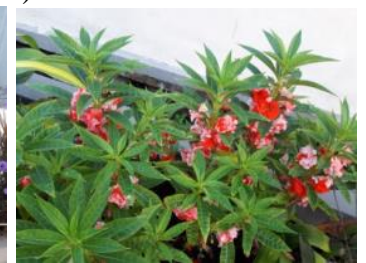

(b)
Gambar 2. Bunga berwarna yang sangat mudah tumbuh di iklim Indonesaia sangat berpotensi sebagai bahan indikator alam dalam pembelajaran kimia (a) ruellia, (b) pacar air

Pacar air (bahasa Latin: Impatiens balsamina L.) adalah tanaman yang berasal dari Asia Selatan dan Asia Tenggara namun telah diperkenalkan ke Amerika pada abad ke-19. Tanaman ini adalah tanaman tahunan atau dua tahunan dan memiliki bunga yang berwarna putih, merah, ungu, atau merah jambu. Bentuk bunganya menyerupai bunga anggrek yang kecil. Tinggi tanaman ini bisa mencapai satu meter dengan batangnya yang tebal namun tidak mengayu dan daunnya yang bergerigi tepinya.

Ruellia Ungu yang sering dijumpai sebagai tanaman hias penutup tanah mirip rumput berbunga. Pada jenis tertentu dapat dimanfaatkan sebagai obat.

Tanaman ruellia dapat tumbuh tinggi mencapai $91 \mathrm{~cm}$. Tangkai bunga yang tidak terlalu panjang membentuk rangkaian dengan daun berbentuk lancet dengan ukuran panjang antara 15 sampai 30 $\mathrm{cm}$ dan lebar $1,3-1,9 \mathrm{~cm}$. Bentuk bunga menyerupai teromprt dengan variasi warna biru metalik samapi ungu cerah mempunyai 5 mahkota dengan diameter mencapai $7 \mathrm{~cm}$.

Ruellia Ungu 'Purple Showers' (Ruellia brittoniana) yang dikenal juga dengan nama lain Mexican Petunia adalah satu diantara spesies tanaman berbunga dari famili Acanthaceae, berasal dari Meksiko, Kepulauan Karibia, serta Amerika Selatan. Ruellia Ungu juga dapat dijadikan sebagai tanaman hias dalam pot, atau tanaman pembatas. Tanaman ini berbunga dari mulai musim semi sampai musim dingin, memerlukan iklim yang hangat dengan tanah yang berdrainase baik. Perbanyakan tanaman bisa lewat biji maupun dengan cara vegetatif lewat stek batang. Tanaman Ruellia ungu gampang tumbuh pada keadaan lingkungan dengan intensitas sinar matahari penuh ataupun dibawah naungan. Keadaan tanah yang pas untuk perkembangan ruellia ungu yaitu tanah dengan kelembapan menengah sampai kelembaban tinggi. Ruellia Ungu dapat menarik kupu-kupu dengan bunganya yang atraktif.

Bunga pacar air dan Ruellia dengan warnawarna yang atraktif ini dimanfaatkan sebagai indikator asam basa alami dalam pembelajaran kimia. Hasil uji coba di laboratorium disajikan pada Tabel 4.

Tabel 4. Data Perubahan Warna Pada Larutan Dengan Berbagai Ph Bunga Pacar Air Dan Ruellia Ungu

\begin{tabular}{|c|c|c|c|c|}
\hline No. & Janis bahan & $\begin{array}{l}\text { Trayek pH dan } \\
\text { perubahan warna }\end{array}$ & Gambar & Keterangan \\
\hline \multirow[t]{8}{*}{1} & Bunga ruelia Ungu & $\mathrm{pH} 1=$ ungu & & \multirow{8}{*}{$\begin{array}{l}\text { Warna lebih bagus menggunakan } \\
\text { pelarut air } \\
\text { Disarankan pakaipelarut air : } \\
\text { - lebih aman (pinsip GC No,12), } \\
\text { tidak mudah menguap (Tidak } \\
\text { lekas habis, dapat dimanfaatkan } \\
\text { lebih banyak (prinsip GC No. 6) }\end{array}$} \\
\hline & & pH $2=$ ungu muda & & \\
\hline & Ruellia Britoniana & $\mathrm{pH} 3-7=$ ungu & 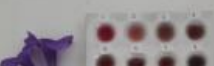 & \\
\hline & Pelarut air & pH $8=$ hijau muda & & \\
\hline & Warna ekstrak ungu & pH $9=$ hijau & - $\operatorname{coc}$ & \\
\hline & pekat & $\mathrm{pH} 10-12=$ hijau & & \\
\hline & & $\begin{array}{l}\text { Kecoklatan } \\
\text { pH } 13=\text { coklat tua }\end{array}$ & & \\
\hline & & pH $14=$ kuning tua & & \\
\hline
\end{tabular}




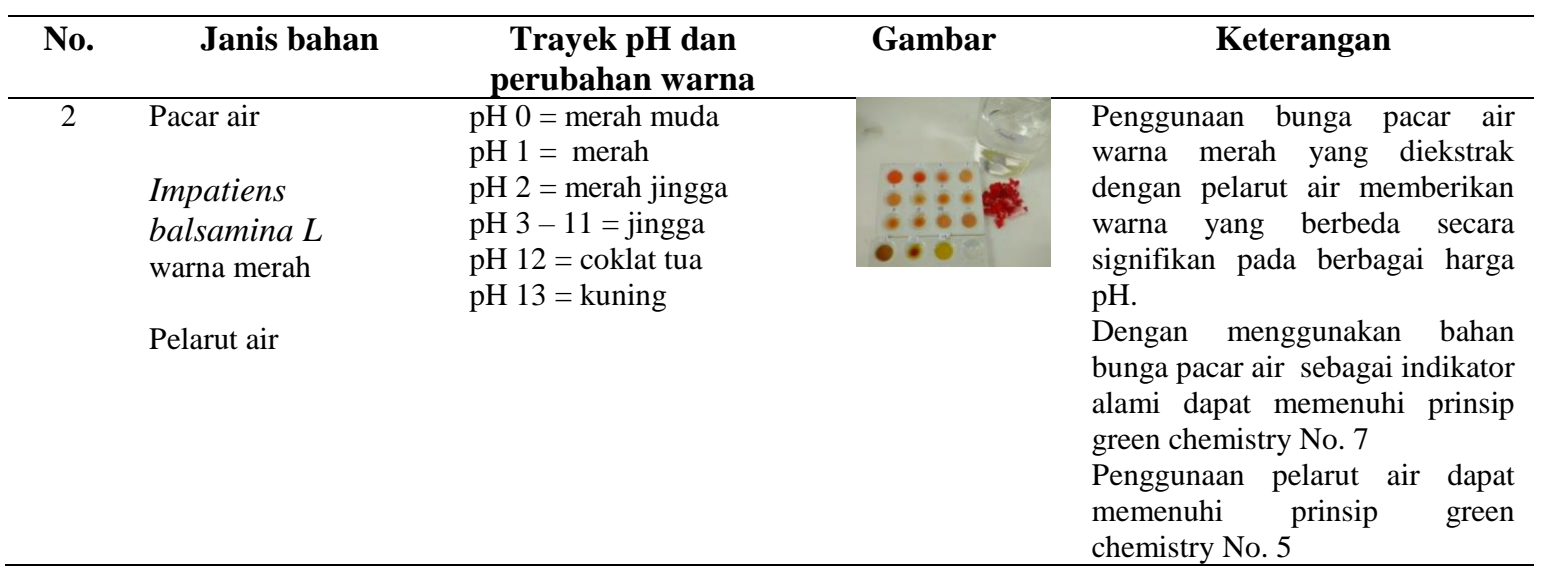

Tabel 4 menunjukkan bahwa ekstrak bunga Ruellia ungu dapat digunakan sebagai indikator asam basa alami dengan menunjukkan perubahan warna pada trayek pH 1 -2 pada suasana asam, sedangkan pada $\mathrm{pH} 3-7$ pada suasana asam sampai netral tidak menunjukkan perbedaan warna yang signifikan. Pada suasana basa $\mathrm{pH} 8-9$ menunjukkan perubahan warna yang signifikan menjadi hijau. Pada pH 10 - 12 tidak berbeda nyata, sedangkan pada suasana yang sangat basa pH $13-14$ berubah menjadi coklat dan kuning tua.

Ekstrak bunga pacar air dapat menunjukkan perubahan warna pada $\mathrm{pH}$ dengan trayek $\mathrm{pH}$ 0-3 pada suasana asam dan $\mathrm{pH} 12-14$ pada suasana basa pada pH 3 -11 tidak menunjukkan perubahan warna yang signifikan, dengan demikian bunga pacar air dan ruellia dapat dimanfaatkan sebagai indikator asam basa alami dan dapat memenuhi prinsip green chemistry no. 7 yaitu penggunaan bahan yang dapat diperbaharui.

\section{KESIMPULAN}

Berdasarkan analisis data dan pembahasan hasil penelitian dapat disimpulkan bahwa pemanfaatan produk alami terbarukan sebagai pendukung pembelajaran dapat memenuhi salah satu prinsip green chemistry yaitu "penggunaan bahan baku terbarukan". Beberapa bunga berwarna diidentifikasi dan berpotensi dimanfaatkan sebagai indikator asam basa alami dalam pembelajaran kimia antara lain bunga pacar air dan Ruellia. Dengan menggunakan bahan alami dapat menjaga keberlanjutan proses pembelajaran kimia tanpa tergantung bahan kimia buatan industri.

\section{DAFTAR PUSTAKA}

Asieh Ahmadalinezhad, Aicheng Chen. 2011. High-performance electrochemical biosensor for the detection of total cholesterol, Biosensors and Bioelectronics 26, $4508-4513$.

Ganesa Flora, 2016. Ruellia Ungu (Ruellia Brtittonania). Online. http://ganeshaflora.blogspot. co.id/ 2016/05/ruellia-unguruellia-britoniana.html diakses 24 Agustus 2017.

Mannahan, 2006. Chemistry, green chemistry, and environmental chemistry. From green chemistry and the Ten Commandments of Sustainability, ChemChar Research, Inc., 2006 manahans@missouri.edu

Miarlis, Bertha Y., \& Rusly, H. 2015. Identifikasi Prinsip Green Chemistry Sebagai Dasar Analisis Nilai Karakter Sains Dalam Rangka Mewujudkan Green Education Yang Terintegrasi Pada Perkuliahan Kimia Dasar. Prosiding Seminar Nasional Hasil Penelitian dan Pengabdian Kepada Masyarakat 2015. Surabaya: LPPM Universitas Negeri Surabaya.

Sjaifullah A., 2011. Developing Speaking Materials For The Students Of Mechanical Engineering At State Polytechnic Of Malang. Jurnal Linguistik Terapan. (online). http://jlt-polinema.org/ accessed 7 November 2015

Sugiarto B., 2007. Kimia Dasar. Jurusan Kimia FMIPA Universitas Negeri Surabaya. Surabaya: Unesa University Press. 